\title{
Anticancer Potential of Plants and Natural Products: A Review
}

\author{
Om Prakash ${ }^{1}$, Amit Kumar ${ }^{1}$, Pawan Kumar ${ }^{1}$, Ajeet ${ }^{2, *}$ \\ ${ }^{1}$ Department of Pharmacy, Sagar Institute of Technology \& Management, Barabanki, Uttar Pradesh, India \\ ${ }^{2}$ S. D. College of Pharmacy and Vocational Studies, Muzafffarnagar, Uttar Pradesh, India \\ *Corresponding author: ajeet_pharma111@rediffmail.com
}

Received October 27, 2013; Revised December 08, 2013; Accepted December 24, 2013

\begin{abstract}
Cancer is one of the leading causes of death and globally the numbers of cases of cancer are increasing gradually. There are several medicines available in the market to treat the various types of cancer but no drug is found to be fully effective and safe. The major problem in the cancer chemotherapy is the toxicity of the established drugs. However plants and plant derived products have proved effective and safe in the treatment and management of cancers. These days most of the research work on cancer drugs is targeted on plants and plants derived natural products. Many natural products and their analogues have been identified as potent anti-cancer agents and day by day the anti-cancer property of various plants is being identified. Here an attempt is being made through this review to highlights the natural products and their analogues established as anti-cancer agents and the new plant species identified with anti-cancer properties either in vivo or in vitro.
\end{abstract}

Keywords: cancer cells, natural products, plants, carcinoma

Cite This Article: Om Prakash, Amit Kumar, Pawan Kumar, and Ajeet, "Anticancer Potential of Plants and Natural Products: A Review.” American Journal of Pharmacological Sciences 1, no. 6 (2013): 104-115. doi: 10.12691/ajps-1-6-1.

\section{Introduction}

Cancer is a major public health burden in both developed and developing countries. It is an abnormal growth of cells in body that can lead to death. Cancer cells usually invade and destroy normal cells. These cells are born due to imbalance in the body and by correcting this imbalance, the cancer may be treated. Billions of dollars have been spent on cancer research and yet we do not understand exactly what cancer is. Every year, millions of people are diagnosed with cancer, leading to death. According to the American Cancer Society, deaths arising from cancer constitute $2-3 \%$ of the annual deaths recorded worldwide. Thus cancer kills about 3500 million people annually all over the world. Several chemo preventive agents are used to treat cancer, but they cause toxicity that restricts their usage.

\subsection{What Causes Cancer?}

Cancer begins with mutations in DNA, which instructs the cells how to grow and divide. Normal cells have the ability to repair most of the mutations in their DNA, but the mutation which is not repaired and causing the cells to grow becomes cancerous [1].

\subsection{Environmental Factors}

Environmental factors which, from a scientist's standpoint, include smoking, diet, and infectious diseases as well as chemicals and radiation in our homes and workplace along with trace levels of pollutants in food, drinking water and in air. Other factors which are more likely to affect are tobacco use, unhealthy diet, not enough physical activity, however the degree of risk from pollutants depends on the concentration, intensity and exposure. The cancer risk becomes highly increased where workers are exposed to ionizing radiation, carcinomas chemicals, certain metals and some other specific substances even exposed at low levels. Passive tobacco smoke manifold increase the risk in a large population who do not smoke but exposed to exhaled smoke of smokers [1].

\subsection{Ayurvedic Concept of Cancer}

Charaka and Sushruta Samhita [2,3] both described the equivalent of cancer as "granthi" and "arbuda" [4]. "Granthi" and "Arbuda" can be inflammatory or devoid of inflammation, based on the doshas involved [5]. Three doshas "Vata, Pitta and Kapha"in body are responsible for disease and the balanced coordination of these doshas in body, mind and consciousness is the Ayurvedic definition of health [6]. Tridoshicarbudasare usually malignant because all three major body humors lose mutual coordination, resulting in a morbid condition [7]. Neoplasm can be classified in Ayurveda depends upon various clinical symptoms in relation to tridoshas.

Group I: Diseases that can be named as clear malignancies, including arbuda and granthi, such as mamsarbuda (sarcomas) and raktarbuda (leukaemia), mukharbuda (oral cancer), and asadhya vrana (incurable or malignant ulcers). 
Group II: Diseases that are not cancers but can be considered probable malignancies, such as ulcers and growths. Examples of these are mamsaja oshtharoga (growth of lips), asadhya galganda (incurable thyroid tumour), tridosaja gulmas, and asadhya udara roga, (abdominal tumours like carcinomas of the stomach and liver or lymphomas).

Group III: Diseases in which there is a possibility of malignancy, such as visarpa, asadhya kamala (incurable jaundice), asadhya pradara (intreatable sinusitis).

\section{Role of Plants As Medicinal and Anti- Cancer Agents}

Plants, since ancient time, are using for health benefits by all cultures as well as source of medicines. It has been estimated that about $80-85 \%$ of global population rely on traditional medicines for their primarily health care needs and it is assumed that a major part of traditional therapy involves the use of plant extracts or their active principles $[8,9,10]$. Although a lot of recent investigations have been carried out for advancements in the treatment and control of cancer progression, significant work and room for improvement remain. The main disadvantages of synthetic drugs are the associated side effects. However natural therapies, such as the use of the plants or plant derived natural products are being beneficial to combat cancer. The search for anti-cancer agents from plant sources started in the 1950s when discovery and development of the vinca alkaloids (vinblastin and vincristine), and the isolation of the cytotoxic podophyllotoxins was carried out [11].

\section{Plant-Derived Anti-Cancer Agents in Clinical Use}

\subsection{Vinca Alkaloids}

The first agents introduced in clinical use were vinca alkaloids, vinblastine (VLB) and vincristine (VCR), isolated from the Catharanthus roseus G. Don. (Apocynaceae).These drugs were discovered during an investigation for oral hypoglycemic agents. While research investigators could not confirm this activity, it was noted that plant extracts reduced significantly white blood cell counts and also caused bone marrow depression in rats. Plant extract also prolong the life of mice bearing a transplantable lymphocytic leukemia. Further extraction and fractionation led to the isolation of two active alkaloids namelyvincristine and vinblastine.The plant was originally endemic to Madagascar, but the samples used in the discovery of vincristine and vinblastin were collected in Philippines and theJamaica. Recently semi-synthetic analogues of vinca alkaloids are vinorelbine (VRLB) and vindesine (VDS). These are primarily using alone or in combination with other chemotherapeutic drugs to combat a variety of cancers. VLB is using for the treatment of lymphomas, leukemias, breast cancer, testicular cancer, lung cancers, and Kaposi's sarcoma. VCR had also showed efficacy against leukemia, particularly acute lymphocytic leukemia in childhood. Of over 2069 anti- cancer clinical trials recorded by the National Cancer Institute as being in progress as of July 2004, over 160 are drug combinations including these agents against a range of cancers [12].

\subsection{Podophyllotoxin Derivatives}

The species of Podophyllaceae family such as Podophyllum peltatum Linn., P. emodii Wallichhave been reported with a long history of therapeutical use, including the treatment of skin cancers and warts. Podophyllum peltatum have been used by the Native Americans for the treatment of "cancer". The interest was promoted by the observation in the 1940s thatan alcohol extract of the dried roots (called podophyllin) cures venereal warts by topical application. The chief cytotoxic therapeutic constituents were identified as podophyllotoxins and have been first isolated in 1880, but its correct structure could only be elucidated in the 1950s with the advancement in spectroscopic techniques. Other closely related podophyllotoxins like lignans were also isolated during this period and became introduced into clinical trials, but they were dropped due to lack of efficacy and unacceptable toxicity. Extensive research studies at Sandoz Laboratories in Switzerland in the 1960s and 1970s led to the development of etoposide and teniposide as clinical agents which are being used in the treatment of lymphomas and bronchial and testicular cancers. Of 2069 anti-cancer clinical trials recorded by the NCI as being in progress as of July 2004, over 150 are drug combinations including etoposide against a range of cancers [13].

\subsection{Taxanes}

A more recent advancement in the development of plantderived chemotherapeutic agents is the development of a class of molecules called taxanes. Paclitaxel also names as taxol was first isolated from the bark of Taxus brevifolia Nutt. (Taxaceae). The use of various parts of $T$. brevifolia and other Taxus species (e.g. T. canadensis Marshall, T. baccata L.) by several Native American tribes for the treatment of some non-cancerous conditions has been documented, while the leaves of $T$. baccata are used in the Ayurveda, with one reported use in the treatment of “cancer”. Paclitaxel biosynthesize and occurs in the leaves of various Taxus species, and the ready semisynthetic conversion of the relatively abundant baccatins to paclitaxel, as well as active paclitaxel analogs, such as docetaxel (Taxotere), has provided a major, renewable natural source of this important class of drugs. Paclitaxel is used in the treatment of wide variety of cancers including breast, ovarian and non-small-cell lung cancer, and has also shown efficacy against Kaposi sarcoma. It has also attracted attention due to its potential in the treatment of psoriasis, multiple sclerosis, and rheumatoid arthritis. Docetaxel, a semisynthetic derivative, is primarily used in the treatment of breast cancer. The importance of this class of anti-cancer agents can be evaluate by the fact that more than one dozen taxanes analogues are in clinical or preclinical development. In addition, of 2069 cancer clinical trials recorded by the NCI as being in progress as of July 2004, 248 are listed as involving taxane-derived drugs, including 134 with paclitaxel (Taxol), 105 with docetaxel (Taxotere), and 10 with miscellaneous taxanes, either as single agents or in 
combination with other anti-cancer agents. In addition, 23 taxanes are in preclinical development [14].

\subsection{Campothecin Derivatives}

Another advancement that was made in the anti-cancer drug is the class of clinically-active agents derived from camptothecin. Campothecin was first isolated from the Chinese ornamental tree, Camptotheca acuminata Decne (Nyssaceae), and known in China as the tree of joy. The extract of C. acuminata was the only extract out of 1000 various plant extracts tested for anti-tumor activity which showed efficacy, and the active constituents isolated was identifies as camptothecin. Camptothecin was introduced to clinical trials by the National Cancer Institute in the 1970s, but withdrawn soon because of reports of severe bladder toxicity. Extensive researches performed by several organizations for a search of more effective camptothecin derivatives and Topotecan (Hycamtin) was developed by SmithKline Beecham (now Glaxo SmithKline), and Irinotecan was developed by the Japanese company, Yakult Honsha, are now in clinical use. Topotecan is used for the treatment of ovarian and smallcell lung cancers, while Irinotecan is used for the treatment of colorectal cancers. Of the 2069 cancer clinical trials recorded by the NCI as being in progress, as of July 2004, 94 or approximately 4.5\% are listed as involving camptothecin-derived drugs, including 64 with irinotecan (CPT-11), 26 with topotecan, and 4 with other miscellaneous analogues, either as single agents or in combination with other anti-cancer agents. In addition, 15 other camptothecin derivatives are in preclinical development [15].

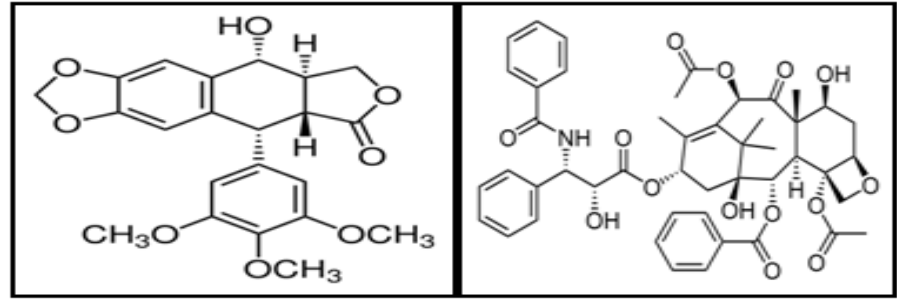

Podophyllotoxin

Taxo1
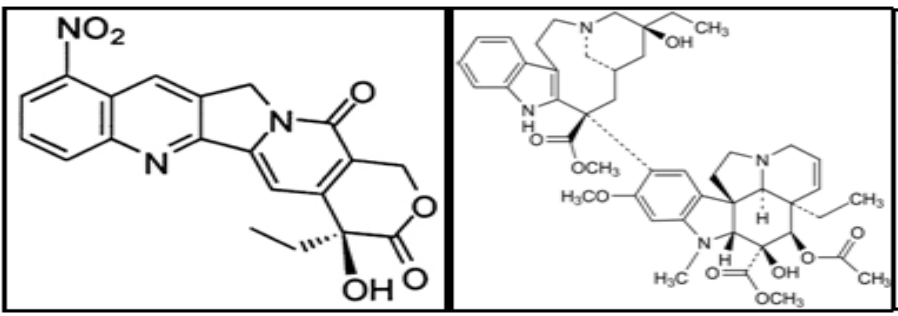

Vinblastin

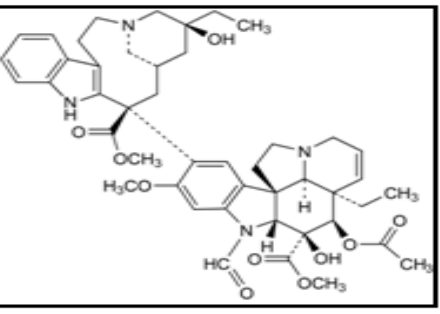

Campothecin

Vincristin

Figure 1. Structures of Plant-Derived Anti-Cancer Agents in Clinical Use

\subsection{Homoharringtonine}

Other plant-derived agents, which are in clinical use, are homoharringtonine. Homoharringtonine was originally isolated from the Chinese tree Cephalotaxus harringtonia var. drupacea (Cephalotaxaceae),. Elliptinium was isolated from species of several genera of the Apocynaceae familyincluding Bleekeria vitensis, a Fijian medicinal plant with reputed anti-cancer properties. A racemic mixture of harringtonine and homoharringtonine (HHT) is being used successfully in China to combat acute myelogenous leukemia and chronic myelogenous leukemia. Purified homoharringtonine has shown efficacy against various leukemias, including some resistant to standard treatment, and has been reported to produce complete hematologic remission in patients with late chronic phase chronic myelogenous leukemia. Elliptinium is marketed in France for the treatment of breast cancer [16].

\section{Plants Proved Effective As Anti-cancer Agent in vivo or in vitro}

\subsection{Achyranthes Aspera}

Achyranthes asperaLinn.(Family-Amaranthaceae) is a commonly found herb as a weed on road sides throughout
India. The methanol extract of Achyranthes aspera, its alkaloid, non-alkaloid and saponin fractions has been exhibited significant inhibitory effects on the Epstein-Barr virus early antigen activation induced by the carcinogen 12-O-tetradecanoylphorbol-13-acetate in Raji cells (at a concentration of $100 \mu \mathrm{g}$ ). In in vitrostudy the non-alkaloid fraction containing mainly nonpolar compounds showed the most significant inhibitory activity [17]. In in vivotwostage mouse skin carcinogenesis test the total methanol extract possessed a pronounced cytotoxic activity [18].

\subsection{Allium Sativum (Allicin)}

Allium sativum (garlic, lasun) is used to treat a wide variety of diseases in India. Allicin is a major component of raw garlic and ajoene is a product of the rearrangement of allicin. Its cytotoxic effect has been tested using human primary fibroblasts, a permanent, nontumorgenic cell line derived from baby hamster kidney cells and a tumorgenic lymphoid cell line derived from a Burkitt lymphoma. The cytotoxic action was in the range $2-50 \mu \mathrm{g} / \mathrm{ml}$ [19]. Some organo-sulfur compounds from garlic, like S-allylcysteine, are reported to retard the growth of chemically induced and transplantable tumors in several animal models [20]. Administration of garlic (250 mg/kg, p.o., thrice a week) in male wistar rats, has been significantely suppressed 4nitroquinoline-1-oxide induced tongue carcinogenesis as 
revealed by the absence by the carcinomas in the initiation phase and their reduced incidence in the post initiation phase [21]. Thus the consumption of garlic may beneficial providing some kind of protection from cancer.

\subsection{Andrographis Paniculata}

Phytochemical investigation of the ethanol extract of the aerial parts of Andographis paniculata has been reported the isolation of 14 compounds; a majority of them are flavonoids and labdane diterpenoids. The cytotoxic activities of these compounds have been evaluated against various cell lines and found that these isolates have a potent tumour inhibitory activity against all investigated cell lines [22]. The methanol extract of Andrographis paniculata was fractionated, dichloromethane fraction reported to possess three active constituents which were further tested and exhibited cytotoxic activity and also potent immunostimulating activity [23]. However, there were also its adverse side effects were also reported which may include gastric upset, headache, bitter taste and fatigue. High doses of Andographis paniculata may have affect the normal functions of liver [24].

\subsection{Annona Muricata}

Graviola is known by its scientific name, Annona muricata. The important class of medicinal components found in graviola is acetogenins. Acetogenins was found in the fruit, seeds, leaves, and bark of the graviola plant. Preliminary research showed that acetogenins block production of adenosine triphosphate, which inhibits the pump that removes cancer drugs from the cell, allowing chemotherapy to be more effective. Furthermore, research suggested that acetogenin may have chemotherapeutic potential, especially against cancer that resistant to multiple drugs [25]. Parkinson like symptoms can occur on oral ingestion of graviola [26]. Some specific acetogenins have been reportedly identified to be toxic for various cancer cell lines like lung solid human-breast cancer, tumor carcinoma, pancreatic carcinoma, prostatic adenocarcinoma, colonic adenocarcinoma, human lymphoma, liver cancer, and multiple-drug resistant human-breast adenocarcinoma [27].

\subsection{Apis Mellifera}

Apis mellifera is the scientific name of honey bee, from which honey is produced. Honey is used to hasten healing of skin wounds, ulcerations, and burns in Indian system of medicine. A protein of the honeybee Apis mellifera has been reported to enhance proliferation of primary-cultured rat hepatocytes and also suppresses apoptosis [28]. It has also showed cytotoxicity in normal human lymphocytes and HL-60 cells [29]. Hamzaoglu et al. (2000) implanated cancer cell into neck wounds of mice, then divided mice into two groups. A significant decrease in wound cancer tumors were observed in the groups of mice that were treated with surgical wounds coated with honey pre and postoperatively. This finding may have some application in human surgery [30].

\subsection{Astralagus Hedysarum}

A polysaccharide from Astralagus hedysarum has shown anti tumor activity. An intraperitoneal injection of $500 \mathrm{mg} / \mathrm{kg}$ resulted in increase in the deposition of the third component of complement (C3) of macrophages in ICR mouse after two hours. The injection of Astralagus hedysarum, when given five times, the proportion of $\mathrm{C} 3$ positive macrophages was more than that of one time injection. The results suggest that Astralagus hedysarum has immuno-potentiating action and can be useful in cancer chemotherapy [31]. Other species of Astragals likeA. membranaceushas also been investigated for its cytotoxic activity. Astragalus membranaceus, has been shown to be capable of restoring the impaired $\mathrm{T}$ cell functions in cancer patients [32]. A. membranaceus was reported to induce monocytic differentiation of human and murine cells in vitro. The studies showed that $A$. membranaceus exhibitedin vitro and in vivo anti-tumor effects, which might be linked with activating the antitumor immune mechanism of the host [33].

\subsection{Bidens Pilosa}

Bidens pilosa is a folk medicine reported with the presence of polyacetylenes, flavonoids, terpenoids, phenylpropanoids and others. An extensive research work on different extracts of Bidens pilosa and further fractionation led to the isolation and characterization of potential marker compound phenyl-1,3,5-heptatriyne. This marker compounds revealed the toxicity profile on normal blood cells in erythrocyte osmotic fragility experiments along with other extracts [34]. Hexane, chloroform and methanol extracts of Bidens pilosa and their fractions were tested on various cancer cell lines. Results exhibited the antitumor activity of extracts among which hexane extract pronounced the most remarkable activity [35].

\subsection{Bolbostemma Paniculatum}

Extraction and further fractionation of chinese herb Bolbostemma paniculatum (Cucurbitaceae) led to the isolation and characterization of a triterpenoid saponin Tubeimoside-V. Further investigations on tubeimoside-V revealed the apoptotic killing nature on glioblastoma cells, thus suggesting its critical role in antitumor chemotherapy [36]. Other tubeimosides like tubeimodes-I, tubeimosideII and tubeimoside-II also exhibited promised cytotoxic activity which may be linked to the inhibition of DNA synthesis and may induce phenotypic reverse transformation of tumor cells [37].

\subsection{Cannabis Sativa}

In vitro studies of components of marijuana (Cannabis sativa) indicate a potential to inhibit human breast cancer cells and to produce tumor eradications. In experiments introducing marijuana to malignant brain tumors, it was found that survival of animals was increased significantly [38]. The active components of Cannabis sativaare cannabinoids. Cannabinoids and their derivatives exert palliative effects in cancer patients by preventing nausea, vomiting and pain and also stimulated the appetite. These compounds have also been shown anti-tumor activity in cell culture and animal models by modulating key cellsignalling pathways [39]. 


\subsection{Centaurea Ainetensis}

The cytotoxic activity of Centaurea ainetensis extracts has been studied in human colon carcinoma cells. The crude extract of Centaurea ainetensis inhibited the proliferation of a host of colon-derived cancer cells. In vivothe crude extract, administered intraperitoneally before administration of subcutaneous injection of 1, 2dimethylhydrazine (a potent carcinogen), reduced the number of tumors and also decreased the mean size of aberrant crypt foci. Further fractionation studies of the crude extract resulted in the isolation and characterization of bioactive sesquiterpene Lactonemolecule called Salograviolide-A, to which the growth inhibition in colon may be linked. Salgraviolide-A reduced the growth of colon cancer cell lines at non-cytotoxic concentrations when administered to normal human intestinal cells. Salograviolide A also exhibited potent cytotoxic action against epidermal squamous cell carcinogenesis [40,41].

\subsection{Camellia Sinensis (Green Tea)}

Epigallocatechin-3-gallate (EGCG) is the most abundant polyphenol in green tea. Some epidemiological studies revealed that EGCG can inhibit the invasion and migration of human colon and oral cancer cells. The effects of EGCG may be partially linked with the decreased productions of MMP-2, MMP-9 and uPA [42]. It was also observed that EGCG inhibit the growth of cancer cell lines like hepatocellular carcinoma through induction of cell cycle arrest [43]. EGCG was also inhibited the growth of cancer cells in ovarian carcinoma cell lines HEY and OVCA, in human colon and rectal cancer cell linesHT-29 and HCA-7 [44,45,46,47]. Apart from EGCG other flavonoids such as rutin, quercetin also linked with anticarcinogencity through inhibition of oxidative activation [48].

\subsection{Daphne Mezereum}

Daphne mezereum is a plant widely used as afolklore remedy for treating cancer like symptoms. A hydro alcohol extract of Daphne mezereumhas exhibited a potent antileukemic activity against lymphocytic leukemia in mice. Further fractionation studies on the extract resulted in the isolation and characterization of mezerein as a potent antileukemic compound [49].

\subsection{Gossypium Hirsutum}

Gossypium hirustum or Gossypium herbaceumalso called as Gossypol or cottonseed oil and used as a male contraceptive, in the treatment of metastatic carcinoma of endometrium or ovary and also used in HIV. Some in vivo and in vitro studies revealed the antitumor properties of gossypol on many cytosolic and mitochondrial enzyme systems that is fundamental for tumor cell growth,including melanoma, endometrial, colon, lung, prostate, breast, brain, and adrenocortical cancer $[50,51,52]$. However no typical dose is yet suggested for the treatment of cancer and self-medication with gossypol is not safe because of its potential toxicity [53].

\subsection{Hydrocotyle Asiatica}

Hydrocotyle asiatica is the scientific name of Gotu kola, brahmi, synonyms with Centella asiatica. In early studies on animal tissue, brahmi exhibited cytotoxic and antitumor properties. It has been found that brahmi increased the life-span of tumor-bearing mice. Brahmi usually is tolerated well when used in typical doses of 600 mg of dried leaves three times a day [54]. A side effect is photosensitivity; therefore, individuals using brahmi are advised to wear sunscreen and clothing to prevent sunburn [55]. An aqueous extract of leaves of brahmi has shown prominent cytotoxic activity against mouse melanoma, human breast cancer, rat glioma cell lines [56]. C. asiatica crude extract and its purified fractions has slowed down the development of solid and ascites tumors, also prolonged the life span of tumors bearing mice. Cytotoxic and antitumour effect involves direct action on DNA synthesis [57]. C. asiatica modulate nitric oxide and tumour necrosis factor-alpha in mouse macrophages [58]. Asiaticoside was found possessing prominent wound healing activity which may be associated with its effect on collagen synthesis. As asiaticoside induce apoptosis and enhance antitumor activity when administered with vincristine, it may be useful in cancer chemotherapy [59]. Asiatic acid was also found having anticancer effect on skin cancer [60].

\subsection{Hypericum Perforatum}

Hypericin is the active constituent which was isolated and characterized from Hypericum perforatum, also called as St.John's Wort. Napthodianthrones are the group of compounds which belong to hyericin. Hypericin reduced and retarded the glioma cell lines growth in vitro and also induced death of glioma cell which was linked to inhibition of Protein Kinase-C, as measured by thymidine uptake. The hypericin's activity to inhibit glioma cells was comparable or greater than tamoxifen which was used as reference standard [61,62]. Hypericum perforatum inhibitory activity was due to its components, whichinhibits serotoninreuptake and thus reduces cell growth on several cancer cell lines, in vitro and in vivo [63].

\subsection{Mangifera Indica}

Mangifera indicais a nutritional supplement used in several tribes and countries as a folklore remedy. This aqueous extract is considered in Cuba beneficial and used in healthy people to reduce environmental, nutritional risk factors, and also prolong the quality of life through increasing free radical scavenging mechanism [64]. Ethno-botanical studies resulted in a great improvement of life quality in cancer patients [65]. Research studies have exhibited immune-modulator effects of mango in different cell lines. The principle active constituents of mango consists of a mixture of terpenoids, polyphenols, steroids, fatty acids and microelements that imparts properties and provide antioxidant supplements [66].

\subsection{Nervilia Fordii}

Nervelia fordii is a drug used in China as a folklore remedy. Petroleum ether and ethyl acetate extracts of Nervilia fordii has been screened out for its anticancer properties using mice models. Both extracts have shown prominent anticancer effects when administered to S-180 mice and H-22 mice models; also prolong the life of cancer bearing mice. This study suggests, Nervilia fordii 
can exploit as cancer inhibiting agent and further research work is required to isolate active constituent/s present in drug [67].

\subsection{Oroxylum Indicum}

Oroxylum indicum (Sonapatha) is used in various polyherbal formulations in Indian system of medicine. Studies have proved anticancer potential of Oroxylum indicum usingvarious models. A 95\% ethanol extract exhibited cytotoxic activity against Hep2 cell lines at a concentration of $0.05 \%$ [68]. Flavonoid baicalein present in Oroxylum indicum has anti-tumour effect on human cancer cell lines and inhibited the $50 \%$ proliferation of HL-60 cell lines at a concentration of 25-30 microM [69]. Methanolic extract of $O$. indicum strongly inhibited the mutagenicity of Trp-P-1 in ames test [70]. Administration of nitrosated $O$. indicum fractions at a dose of $0.25-2 \mathrm{~g} / \mathrm{kg}$ body weight has genotoxic and cell proliferative activity in the pyloric mucosa of rat stomach in vivo [71]. Extract of Oroxylum indicum showed the toxicity on tumor cell lines tested, with an $\mathrm{IC}_{50}$ value $19.6 \mu \mathrm{g} / \mathrm{ml}$ for CEM, 14.2 $\mu \mathrm{g} / \mathrm{ml}$ for HL-60, $17.2 \mu \mathrm{g} / \mathrm{ml}$ for B-16 and $32.5 \mu \mathrm{g} / \mathrm{ml}$ for HCT-8 [72]. The methanolic and aqueous extracts of Oroxylum indicum have been demonstrated extensive cytotoxicity in selected tested cell lines, with the methanolic extract showing greater cytotoxic potential. Both extracts exhibited moderate levels of DNA protection against oxidative stress [73].

\subsection{Picrorrhiza Kurroa}

Picrorrhiza kurroa (Kutki) used as a hepatoprotective remedy in indian system of medicine, inhibited liver cancer growth formed due to exposure of chemicals in animal studies. Kutkin is the active constituent of herb which is a combination of picrosides and kutkosides. Kutkin is found to inhibit level of lipid peroxidases, hydroperoxidases, free radical producing agents and also facilitates the recovery of antioxidant SOD, which is needed to prevent the liver from oxidative damage [74].

\subsection{Rubia Cordifolia}

The hexapeptides and quinones found in Rubia cordifolia have showed a prominent antitumor activity by binding to eukaryotic 80S ribosomes. This binding resulted in inhibition of aminoacyl-tRNA binding and peptidyl-tRNA translocation, which is a necessary mechanism for protein synthesis [75,76,77]. Mollugin is a constituent that was isolated from chloroform extract of Rubia cordifolia roots. Mollugin has shown a significant activity against lymphoid leukemia in mice and also showed the inhibition of passive cutaneous anaphylaxis, protection of mast cells degranulation in rats [78]. A mitodeprssive effect was observed on the rate of cell division in bone marrow of Swiss mice, which was attributed to the effect of inhibiting protein synthesis [79]. The cytotoxic action of Rubia cordifolia had been evaluated with DNA Topoisomerases I and II inhibition and cytotoxicity of constituents isolated from the roots was tested. Topoisomerases I and II inhibitory activities were measured by assessing the relaxation of supercoiled pBR 322 plasmid DNA. The tetrazolium-based colorimetric assay (MTT assay) was used for the cytotoxicity towards human colon carcinoma, human breast carcinoma and human livercarcinoma (HepG2) cell lines. Seven compounds were isolated possessing cytotoxic activity [80].

\subsection{Salvia Miltiorrhiza}

Tanshinone-I was isolated from traditional herbSalvia miltiorrhizae, was investigated on the expression of intercellular adhesion molecule. The study revealed a potential anticancer effect of tanshinone I on breast cancer cells, suggesting that tanshinone-I may serve as an effective drug for the treatment of breast cancer. [81]. Tanshinone II-A, isolated from Salvia miltiorrhiza, induced apoptosis which was linked to proteolytic cleavage of a major component in apoptotic cell death mechanism [82].

\subsection{Scutellaria}

Scutellaria is a genus of traditional herbal species with potential anti-cancer activity. Common biologically active flavonoids found in Scutellaria species are apigenin, baicalein, baicalin, chrysin, scutellarein, and wogonin. The flavonoids of Scutellaria species exhibited anti-tumor activity as well as positive interactions with different mechanism of actions. Among the different extracts tested, leaf extracts of Scutellaria angulosa, Scutellaria integrifolia, Scutellaria ocmulgee and Scutellaria scandens were found to possess a potent anticancer activity [83]. Yin et al., (2004) revealed the tumor inhibitory effect of Scutellaria barbata and explained its mechanism using human lung cancer cell line A549. Scutellaria barbata ethanol extract significantly reduced the growth of A549 cell, with an IC $_{50}$ value of $0.21 \mathrm{mg} / \mathrm{ml}$ [84]. Tanshinone IIA, also isolated from herb might have potential anticancer activity on breast cancers, apoptosis, signal transduction, cell proliferation, transcriptional regulation, angiogenesis, invasive potential and metastatic potential of cancer cells [85]. Microarray and pathway analysis of tumor related genes identified the differentially expressed genes responding to tanshinone I and suggest that tanshinone I exhibits anticancer effects both in vitro and in vivo [86]. Other species of Scutellaria like S.baicalensis, Scutellaria litwinowii etc. have proved recently as a potent anticancer agent in various in vitro as well as in vivo models $[87,88,89]$.

\subsection{Silybum Marianum}

Silymarinis a flavonoid compound isolated from the milk thistle plant Silybum marianum. Silymarin was studied against UV radiation induced skin cancer in mice. Silymarin treatment reduced the chances of tumor incidence to $60 \%$, tumor multiplicity $78 \%$, and tumor volume per mouse was also reduced to $90 \%$ and thus exhibited a prominent anticancer activity [90]. The probable mechanism of silymarin can be its suppression of proliferation of tumor cells; this is accomplished through cell cycle arrest at the G1/S-phase, induction of cyclindependent kinase inhibitors, down-regulation of antiapoptotic gene products, inhibition of cell-survival kinases and inhibition of inflammatory transcription factors. Silymarin was also found to down regulate gene 
products associated in the proliferation of tumor cells, invasion, angiogenesis and metastasis [91]. Silibinin, a major constituent (flavanolignan) of the fruits of Silybum marianumalsobeneficial in human breast cancer [92].

\subsection{Smilax China}

Kaempferol-7-O-beta-D-glucoside (KG), a flavonoid glycoside is the active constituent isolated from Smilax china $L$. rhizomes. KG has revealed a significant anticancer effect on cancer cells of which human cervix carcinoma cells were found more sensitive. It exerts its cytotoxic effect through arresting of cell cycle and induction of apoptosis in cells, suggesting that KG can be used as a therapeutic remedy for cervix carcinomas [93,94].

\subsection{Strychnos Nuxvomica}

Strychnos nuxvomica, belongs to the family Loganiaceae, is largely collected from forests of Indian subcontinent and Northern Australia. Strychnos nuxvomica has revealed cytotoxic activity against multiple myloma cell line- ROMI 8226. Root extract of Strychnos nuxvomica was screened using the same cell lines and exhibited anticancer activity in a dose and time dependent manner [95]. Major constituents present in Strychnos nuxvomicaare of alkaloidal nature and effective against HepG2 cells proliferation, among which brucine alkaloid proceed HepG2 cells death via apoptosis, through the participation of caspase-3 and cyclooxygenase-2 [96].

\subsection{Taraxacum Officinale}

Dandelions are common name of plants belong to genus Taraxacum. Taraxacum have a long history of use in several tribes and countries and also used to combat a wide variety of diseases including cancer. Leaves, flowers and root extracts of Taraxacum officinalewas investigated against tumor progression related processes such as invasion and proliferation. Among all the extracts, leaf extract of Taraxacum officinalereduced the growth of breast cancer cells [97]. The Taraxacum officinaledecreased the cell viability and significantly increased the tumor necrosis factor (TNF)- $\alpha$ and interleukin (IL)-1 $\alpha$ production [98].

\subsection{Terminalia Chebula}

Terminalia chebulais a source of hydrolysable tannis and its antimutagenic activity in Salmonella typhimuriumhas been documented [99]. Phenols like chebulinic acid, tannic acid, ellagic acid are the cancer growth inhibitors found in the fruits of Terminalia chebula [100]. Terminalia chebula fruits powder and its acetone extract of bark have been reported with promising antimutagenic and anticarcinogenic activity [101].

\subsection{Vernonia Amygdalina}

Vernonia amygdalina (VA), member of the Compositae family, is a small shrub that grows in the tropical Africa. The in vivo studies were conducted using sixty 5-6 week old female athymic nude mice. Mice were injected subcutaneously with 106 MCF-7 breast cancerous cells in the flank area and monitored for tumor growth. Compared to the negative control mice, VA completely reversed or eliminated the tumors of the animal in both treatment groups. Immuno histochemical data revealed that VA increased basal apoptotic but decreased angiogenic activities in both breast cancernoma cells [102].

\subsection{Withania Somnifera (Withanolides)}

Withaferin-A is a withanolide isolated from the roots of Withania somnifera. Withaferin-A has been shown a significant tumor reducing activity in carcinomas like carcinoma of nasopharynx, Sarcoma 180, Sarcoma Black and E 0771 mammary adenocarcinoma. Withania somnifera is highly appreciated in Ayurveda for cancer patients and also used as a folklore remedy for combating the cancer like conditions, also prolong the life [103,104,105].

The Withania somnifera root extract's chemo preventive effect has been evaluated in a study on induced skin cancer in mice administering WS before and during exposure to the skin cancer causing agent 7, 12dimethylbenz(a)anthracene. A significant decrease in incidence and average number of skin lesions was observe when compared to the control and standard groups [106]. An in vitro study showed withanolides from Withania somnifera reduced the growth of cancer cells in human breast, central nervous system, lung, and colon cancer cell lines comparable to doxorubicin, which was used as standard drug. Withaferin A was found more effective than standard drug doxorubicin [107]. Withania somnifera has also been evaluated for its antitumor effect in urethane induced lung adenomas in adult male albino mice. The histological appearance of the lungs of animals protected by Withania somnifera extract was found similar to those observed in the lungs of control animals. The treatment of drug extract also reversed the adverse effects of urethane on total leukocyte count, lymphocyte count, body weight, and mortality [108]. A significant increase in the life span and a decrease in the cancer cell number and tumour weight were noted in the tumour-induced mice after treatment with WS. These observations are suggestive of the protective effect of Withania somnifera in carcinogens [109].

\subsection{Zingiber Officinale}

Zingiber officinale ethanol extract was investigated to find out its antitumor effects in skin tumorigenesis model. Pre-application of Zingiber officinale ethnol extract onto the skin of mice resulted in significant inhibition of 12-0tetradecanoylphorbol- 13-acetate (TPA)-caused induction of epidermal ODC, cyclo oxygenase, and lipoxygenase activities and ODC mRNA expression in a dosedependent manner. Pre-application of Zingiber officinaleethanol extract to mouse skin also resulted in a significant inhibition of TPAcaused epidermal edema and hyperplasia. In prolonged time studies, topical application of Zingiber officinale ethanol extract thirty minute prior to that of each TPA application to 7, 12-dimethylbenz(a)anthracene initiated mice caused amarked protection against skin tumor incidence its multiplicity [110].

Ginger's natural bio-actives, specifically ginger extract and 6-gigerol, have also been investigated for their in vitro inhibition of two key aspects of colon cancer biology, cancer cell proliferation and angiogenic potential of endothelial cell tubule formation. These active ginger 
constituents linked to a direct effect on cancer cells. Among other compounds, 6-gingerol was found more effective even at lower doses resulted in inhibition of endothelial cell tube formation [111]. The suggested mechanism of action of Ginger extract on colon cancer cells may be its suppression and arresting the G0/G1-phase, reducing DNA synthesis and inducing apoptosis [112].

Table 1. Other Anti-cancer Plants [118,119,120]

\begin{tabular}{|c|c|c|c|}
\hline Botanical name of plant with family name & Part used & Parts used and their main active components & $\begin{array}{l}\text { Origin / native } \\
\text { place }\end{array}$ \\
\hline Agave americana (Agavaceae) & Leaf & $\begin{array}{c}\text { Steroidal saponin, alkaloid, coumarin, isoflavonoid, hecogenin } \\
\text { and vitamins (A, B, C) }\end{array}$ & Central America \\
\hline Agropyron repens (Poaceae) & Rhizomes & Rhizome contains essential oil, polysaccharide and mucilage & Europe \\
\hline Agrimonia pilosa (Rosaceae) & Herb & Agrimonolide, flavonoid, triterpene, tannin and coumarin & $\begin{array}{l}\text { China, Japan, } \\
\text { Korea, India }\end{array}$ \\
\hline Ailanthus altissima (Simaroubaceae) & Bark & Triterpene, tannin, saponin and quercetin-3-glucoside & China, Korea \\
\hline Akebia quinata (Lardizabalaceae) & Fruit & Flavonoid and saponin & China, Japan, Korea \\
\hline Alpinia galanga (Zingiberaceae) & Rhizomes & Kaempferide and flavone & Europe \\
\hline Aristolochia contorta (Aristolochiaceae) & Root and fruit & Lysicamine and oxaaporphine & China, Korea \\
\hline Aster tataricus (Asteraceae) & Whole plant & Triterpene, monoterpene and epifriedelanol & Japan, Korea \\
\hline Bryonia dioica & Root & Cucurbitacin and glycoside & Europe \\
\hline Cannabis sativa (Cannabinaceae) & Leaf & Stereo isomers of cannabitriol & South Africa \\
\hline $\begin{array}{l}\text { Chelidonium jajus var. asiaticum } \\
\text { (Papaveraceae) }\end{array}$ & Herb & Alkaloids (sanguinarine, chelerythrine, berberine) & Asia, Europe \\
\hline Chimaphila umbellate (Ericaceae) & Whole plant & Ericolin, arbutin, urson and tannin & Asia, Europe \\
\hline Coix lachryma jobi (Poaceae) & Seed & Trans-ferulyl stigmasterol & China \\
\hline Dryopteris crassirhizoma (Polypodiaceae) & Rhizomes & Filicinic and filicic acids, aspidinol and aspidin & China, Japan, Korea \\
\hline Echinops setifer (Asteraceae) & Whole plant & Echinopsine & Korea \\
\hline Erythronium americanum (Liliaceae) & Whole plant & Alpha-methylenebutyrolactone & North America \\
\hline Euonymus alatus (Celastraceae) & Whole plant & Triterpene, euolatin, steroid and sesquiterpene alkaloid & China, Japan, Korea \\
\hline Eupatorium cannabinum (Asteraceae) & Whole plant & Sesquiterpene, lactone, pyrrolizidine alkaloidand flavonoid & Europe, Asia, \\
\hline Fragaria vesca (Rosaceae) & Leaf and fruit & Flavonoid, tannin, borneol and ellagic acid Asia, Europe & Asia, Europe \\
\hline Fritillaria thunbergii (Liliaceae) & Whole plant & Alkaloid and peimine & China, Siberia \\
\hline Galium aparine (Rubiaceae) & Cleaver & Iridoid, polyphenolic acid, tannin, anthraquinoneand flavonoid & Europe, Africa \\
\hline Hydrastis canadensis (Ranunculaceae) & Whole plant & $\begin{array}{l}\text { Isoquinoline alkaloids (hydrastine, berberine, berberastine, } \\
\text { candaline), resin and lactone }\end{array}$ & $\begin{array}{l}\text { Canada, United } \\
\text { States }\end{array}$ \\
\hline Junchus effuses (Juncaceae) & Whole plant & $\begin{array}{l}\text { tridecanone, effusol, juncanol, phenylpropanoid and a- } \\
\text { tocopherol }\end{array}$ & China, Japan, Korea \\
\hline Lantana camara (Verbenaceae) & Whole plant & $\begin{array}{l}\text { Alkaloids (camerine, isocamerine, micranine,lantanine, } \\
\text { lantadene) }\end{array}$ & Tropical America \\
\hline Larrea tridentate (Zygophyllaceae) & Whole plant & Resin & $\begin{array}{l}\text { Southwestern } \\
\text { USA,Mexico }\end{array}$ \\
\hline Lonicera japonica (Caprifoliaceae) & Whole plant & Tannins, saponins and carotenoids & China \\
\hline Olea europrae (Oleaceae) & Leaf and oil & Oleic acid and polyphenol & America \\
\hline Panax quinquefolium (Araliaceae) & Roots & Ginsenoside, sesquiterpene, limonene vitamins $\left(\mathrm{B}_{1}, \mathrm{~B}_{2}, \mathrm{~B}_{12}\right)$ & China, Japan, Korea \\
\hline Phaleria macrocarpa & Fruits & Gallic acid & Indonesia \\
\hline Polygonatum multiflorum (Liliaceae) & Whole plant & Saponin, flavonoid and vitamin A & $\begin{array}{l}\text { Asia, Europe, North } \\
\text { America }\end{array}$ \\
\hline Potentilla chinensis (Rolsaaceae) & Whole plant & Gallic acid and tannin & China, Japan, Korea \\
\hline Pygeum africanum (Boraginaceae) & Bark & Phytosterol, triterpene and tannin & Africa \\
\hline Pyrus malus (Rosaceae) & Bark and fruit & $\begin{array}{l}\text { Quercetin, catechin, flavonoid, coumaric and gallic acids, and } \\
\text { procyanidin }\end{array}$ & Britain \\
\hline Rhus chinensis (Anacardiaceae) & Leaf & $\begin{array}{l}\text { Tannin, apigenin and glycoside; seed contains bruceosides (A, } \\
\text { B), }\end{array}$ & China, Japan, Korea \\
\hline Rubus idaeus (Rosaceae) & Leaf & $\begin{array}{l}\text { Flavonoid and tannin; fruit contains vitamins (A, B, C) and } \\
\text { ellagic acid }\end{array}$ & Asia, Europe \\
\hline Scilla natalensis (Hyacinthaceae) & Bulb & Bulb & South Africa \\
\hline Scrophularia nodosa (Scrophulariaceae) & Aerial parts & Iridoid, flavonoid and phenolic acid & Europe \\
\hline Smilax chinensis (Liliaceae) & Rhizomes & Tannin, saponins and flavonoid & China, Japan \\
\hline Tabebuia spp. (Bignoniaceae) & Bark & Quinine, bioflavonoid and co-enzyme Q & South America \\
\hline Thuja occidentalis (Cupressaceae) & Whole plant & Flavonoid, tannin, volatile oil and mucilage & $\begin{array}{l}\text { Northeastern USA, } \\
\text { Europe }\end{array}$ \\
\hline Thymus vulgaris (Lamiaceae) & Whole plant & Volatile oil, flavonoid and tannin & South Europe \\
\hline Trifolium pratense (Fabaceae) & Flower & Glucosides (trifolin, trifolitin, trifolianol), flavonoid & $\begin{array}{l}\text { Asia, Europe, } \\
\text { Africa, Australia }\end{array}$ \\
\hline Vitex rotundifolia(Verbenaceae) & Whole plant & & China, Japan, Korea \\
\hline \multicolumn{4}{|c|}{$\begin{array}{l}\text { showed that three plants, } A \text {. indica, B. pandurata, and } C \text {. } \\
\text { fenestratum, exhibited high cytotoxic activity against the } \\
\text { Hep2 cell lines at a minimum concentration of } 0.05 \% \text { in }\end{array}$} \\
\hline
\end{tabular}


the most potent cytotoxic extract based on its lowest $\mathrm{IC}_{50}$ $(5 \mathrm{mg} / \mathrm{mL})$. All of these extracts resulted in a reduction of cell proliferation of Hep2 cells at four and eight hour's incubation. When incubated for eight hour, Azadirachta indica and B. pandurata resulted in 95\% inhibition of cell proliferation, while C. fenestratum provided $80 \%$ inhibitions respectively [68,73].

Calotropine, a glycoside present in Calotropis procera (Aak) has shown anti tumor activity against human epidermoid carcinoma cells of rhinopharynx in vivo studies [113]. Calotropis procera inhibited the growth of cells and mitotic activity in a dose-dependent manner in vitro [114]. Ellipticine, an indole alkaloid isolated from Ochrosia ellipitica, is a potent topoisomerase inhibitor [115]. Curcumin, the active constituent of Curcuma domestica, has potent anticancer activity in animal models [116]. Homoharringtonine, an alkaloid from Cephalotaxus homoharringtonia, when combined with cytarabine, has shown activity in chronic myelogenous leukemia (CML) in a study 105 patients received continuous infusion of homoharringtonine $2.5 \mathrm{mg} / \mathrm{kg} / \mathrm{m} 2 /$ day plus subcutaneous cytarabine $15 \mathrm{mg} / \mathrm{kg} / \mathrm{m} 2 /$ day for five weeks. L-Canavanine isolated from Medicago sativa and Canavalia esniformis, has shown significant antineoplastic activity in animal models bearing carcinoma and cancer cell lines [116,117].

\section{Some Promising Plant-derived Anticancer 'Leads'}

Plants since the time immemorial have been regarded as a source of medicines and numerous types of bioactive substances have been isolated and characterized as therapeutic agents. A number of such molecules are under clinical studies. A synthetic flavone favopiridol, originally derived from the plant alkaloid rohitukine and isolated from Dysoxylum binectariferum is currently under phase I and phase II clinical trials. This flavone has shown its broad activity against tumors, leukemia, lymphomas and solid tumors [122]. Olomucine is a natural product isolated from Raphanus sativus (Brassicaceae), has converted into a synthetic agent roscovitine. Roscovitine is in Phase II and Phase III clinical trials in Europe [123]. Isolation studies on the bark of Combretum caffrum (Combretaceae) resulted in the characterization of combretastatins [124]. Combretastatin A-4 has been found effective against lung and colon cancers, leukemia and it is presumed this is the most cytotoxic phytomolecule isolated so far $[125,126]$. Betulinic acid is a common pentacyclic triterpenoid found in the species of genus Betula has proved a significant growth inhibitory agent [127]. Betulinic acid was also isolated from Zizyphus species, like Zizyphusmauritiana, Zizyphusrugosa and Zizyphus oenoplia [128,129] and exhibited selective cytotoxic activity against human melanoma cell lines [130]. The efforts of National Cancer Institute to develop systemic and topical formulations for potential clinical trials are ongoing. Phytochemical studies on roots of Erythroxylum prvillei (Erythroxylaceae) has resulted in the isolation of Pervilleine-A [131]. In a study conducted on multidrug resistant oral epidermoid cancer cell lines, Pervilleine-A was found cytotoxic when administered with anticancer agent vinblastine and this compound is under preclinical development [132]. Silvesterol was isolated from the fruits of Meliaceae family plant Aglaila sylvestre exhibited cytotoxicity against breast and lung cancer cells [133]. Different studies are ongoing to determine the exact mechanism of action for silvesterol and other bioactive molecules [134]. Isolation studies on the seeds of Centaurea schischkinii and Centaurea montanahas been resulted in the isolation of two novel alkaloids schischkinnin and montamine. Schischkinnin and montamine both exhibited anticancer activity against human cancer cells. The molecular skeleton of these novel alkaloids can be exploited for synthesizing compound to enhance cytotoxic activity [135].

\subsection{Natural Products As Leads for Anticancer Drug Discovery}

Epothilones are bacterial macrolides with potent microtubule-stabilizing and antiproliferative activity, which have served as successful lead structures for the discovery of several clinical candidates for cancer treatment. Seven epothilone-type agents have been advanced to clinical evaluation in humans so far and one of these has been approved by the FDA in 2007 for clinical use in breast cancer patients [136].

\section{Conclusion}

This review paper provides information on herbs and natural products with potential to decrease growth of cancer or be used as adjuvant with cancer treatments for patients who already have or have had cancer. It is documented that medicinal herbs have rich anticancer potential, and on the forefront whenever we talk about anticancer remedies, are significant source of synthetic and/or herbal origin. Natural products discovered from medicinal plants have played an important role in the treatment of cancer. They have exhibited anticancer activity in animal models of leukemia, skin cancer and sarcomas. Through generating awareness regarding usage of herbs and exploring natural product properties, healthcare professionals, can play significant clinical roles as knowledge resources for masses. From information from this review health care professionals can initiate discussion with colleagues to determine whether patient may benefit from from taking a specific herb or natural product. Selected plants have been explored for biological activity and further investigations into anticancer activity of the plants showing promising activity, must be undertaken. Vinca rosea alkaloids, Vinblastine and Vincristine, are one of the most potent anticancer drugs known. Taxol isolated from Taxus brevifolia has figured high in the therapeutic segment of cancer. Cancer being associated with high mortality rates if herbs can be used even in the palliative care or to reduce the side effects associated with cancer would be of great relief for the sufferer.

\section{References}

[1] Krishnamurthi K. Screening of natural products for anticancer and antidiabetic properties. Health Administrator. XX (1\&2): 69, (2000).

[2] Charaka. Charaka Samhita. Chaukhamba Publications, Varanasi, India; 700 BC: 215.

[3] Susruta. Susruta Samhita. Chaukhamba Publications, Varanasi, India ; 700 BC: 520 
[4] Misra B. Bhawa Prakash Nighantu. Chaukhamba Publications, Varanasi, India; 1600 AD: 298.

[5] Kapoor L. D. Handbook of ayurvedic medicinal plants. CRC Press, Florida; 1990.

[6] Balachandran P, Govindarajan R., Cancer- an ayurvedic perspective. Pharmacology Research, 51. 19. 2005.

[7] Singh R. H., An assessment of the ayurvedic concept of cancer and a new paradigm of anticancer treatment in Ayurveda. Journal of Alternative \& Complementary Medicine, 8. 609. 2002.

[8] Ignacimuthu S, Ayyanar M, Sivaraman S.K., Ethnobotanical investigations among tribes in Madurai district of Tamil Nadu (India). Journal of Ethnobiology and Ethnomedicine, 2. 1. 2006.

[9] Elujoba A. A., Odeleye O. M., Ogunyemi C. M., Traditional medicine development for medical and dental primary health care delivery system in Africa. African Journal of Traditional, Complementary and Alternative Medicines, 2. 46. 2005.

[10] Tomlinson T. R., Akerele O., Medicinal plants: their role in health and biodiversity. University of Pennsylvania Press, Philadelphia, 1998.

[11] Gordon M. C., David J., Plants as a source of anti-cancer agents. Journal of Ethnopharmacology, 100. 72. 2005.

[12] Gueritte F., Fahy J., The vinca alkaloids. In Anticancer Agents from Natural Products, edited by Cragg GM, Kingston DGI, Newman DJ. Brunner-Routledge Psychology Press, Taylor \& Francis Group, Boca Raton, Chapter 7. 23. 2005.

[13] Lee K.H., Xiao Z., Podophyllotoxins and analogs. In Anticancer Agents from Natural Products, edited by Cragg GM, Kingston DGI, Newman DJ. Brunner-Routledge Psychology Press, Taylor \& Francis Group, Boca Raton, Chapter 5. 71. 2005.

[14] Kingston D. G. I., Taxol and its analogs. In Anticancer Agents from Natural Products, edited by Cragg GM, Kingston DGI, Newman DJ. Brunner-Routledge Psychology Press, Taylor \& Francis Group, Boca Raton, Chapter 6. 89. 2005.

[15] Rahier N.J., Thomas C. J., Hecht S. M., Camptothecin and its analogs. In Anticancer Agents from Natural Products, edited by Cragg GM, Kingston DGI, Newman DJ. Brunner-Routledge Psychology Press, Taylor \& Francis Group, Boca Raton, Chapter 2. 5. 2005.

[16] Itokawa H., Ibraheim Z. Z, Ya F. Q., Takeya K., Anthraquinones, naphthohydroquinones and naphthohydroquinone dimmers from Rubia cordifolia and their cytotoxic activity. Chemical and Pharmaceutical Bulletin, 41(10). 1869. 1993.

[17] Bhoomika R., Ramesh K. G., Anita A.M., Phyto-pharmacology of Achyranthes aspera: A Review. Pharmacognosy Reviews, 1(1). 143. 2007.

[18] Cha kraborty A., Brantner T., Mukainaka Y., Nobukuni M., Kuchide T., Konoshima H., et al., Cancer chemopreventive activity of Achyranthes aspera leaves on Epstein-Barr virus activation and two-stage mouse skin carcinogenesis. Cancer letters, 177(1). 1. 2002.

[19] Scharfenberg K., Wagner R., Wagner K.G., The cytotoxic effect of ajoene, a natural product from garlic, investigated with different cell lines. Cancer Letters, 53(2-3). 103. 1990.

[20] Thomson M., Ali M., Garlic (Allium sativum): a review of its potential use as an anti-cancer agent. Current Cancer Drug Targets, 3(1). 67. 2003.

[21] Banasenthil S., Ramachandran C.R., Nagini S., Prevention of 4nitroquinoline-1-oxide induced rat tongue carcinogenesis by garlic. Fitoterapia, 72. 524. 2001.

[22] Geethangili M., Rao Y. K., Fang S. H., Tzeng Y. M., Cytotoxic constituents from Andrographis paniculata induce cell cycle arrest in jurkat cells. Phytotherapy Research, 22(10). 1336. 2008.

[23] Kumar R.A., Sridevi K., Kumar V. N., Nanduri S., Rajagopal S., Anticancer and immunostimulatory compounds from Andrographis paniculata. Journal of Ethnopharmacology, 92(2-3). 291. 2004.

[24] http://www.zhion.com/herb/Andrographis.html. (Accessed on july 28, 2011).

[25] Muriel J. M., Herbs or Natural Products That Decrease Cancer Growth. Oncology Nursing Forum, 31(4). E 75, 2004.

[26] Lannuzel A., Michel P.P., Caparros L. D., Abaul J., Hocquemiller R., Ruberg M., Toxicity of Annonaceae for dopaminergic neurons: Potential role in atypical Parkinsonism in Guadeloupe, Movement Disorders: Official Journal of the movement Disorder Society, 17: 84, (2002).

[27] http://herbalguides.com/guides/graviola. (Accessed on July 12, 2011).

[28] Kamakura M, Sakaki T., A hypopharyngeal gland protein of the worker honeybee Apis mellifera L. enhances proliferation of primary-cultured rat hepatocytes and suppresses apoptosis in the absence of serum. Protein Expr Purif, 45(2). 307. (2006).

[29] Lee Y. J., Kang S. J., Kim B. M., Kim Y. J., Woo H. D., Chung H. W., Cytotoxicity of honeybee (Apis mellifera) venom in normal human lymphocytes and HL-60 cells. Chemical Biology Interaction, 169(3). 189. (2007).

[30] Hamzaoglu I., Saribeyoglu K., Durak H., Karahasanoglu T., Bayrak I., Altug T., et al., Protective covering of surgical wounds with honey impedes tumor implantation. Archives of Surgery, 135. 1414, (2002).

[31] Wang J., Ito H., Shimura K., Enhancing effect of antitumor polysaccharide from Astralagus or Radix hedysarum on C3 cleavage production of macrophages in mice. Department of Pharmacology, Mie University School of Medicine, Japan. MemInst Oswaldo Cruz, 86(2). 159. (1991).

[32] Cho WC, Leung KN. In vitro and in vivo anti-tumor effects of Astragalus membranaceu. Cancer Letters, 252(1). 43. (2007).

[33] William C. S.C., Kwok L. N., In vitro and in vivo anti-tumor effects of Astragalus membranaceus. Cancer Letters, 252(1). 48. 2007.

[34] Kumari P., Misra K., Sisodia B.S., Faridi U., Srivastava S., Luqman S., et al., A promising anticancer and antimalarial component from the leaves of Bidens pilosa. Planta Medica, 5(1). 59. 2009.

[35] Sundararajan P., Dey A., Smith A., Doss A.G., Rajappan M., Natarajan S., Studies of anticancer and antipyretic activity of Bidens pilosa whole plant. Africa Health Sciences, 6(1). 27. 2006.

[36] Guang C. Y. Z., Xiang Z. H. F. T., Wei D.C., Da K. G., Xi L. W., Tubeimoside V (1), a new cyclic bisdesmoside from tubers of Bolbostemma paniculatum, functions by inducing apoptosis in human glioblastoma U87MG cells. Bioorganic \& Medicinal Chemistry Letters, 16(17). 4575. 2006.

[37] Yu L, Ma R, Wang Y, Nishino H. Potent anti-tumor activity and low toxicity of tubeimoside 1 isolated from Bolbostemma paniculatum. Planta Medica, 60 (3). 204. (1994).

[38] Galve-Roperh I., Sanchez C., Cortes M. L., Pulgar T. G., Izquierdo M., Guzman M., Anti-tumoral action of cannabinoids: Involvement of sustained ceramide accumulation and extracullar signal-regulated kinase activation. Nature Medicine, 6. 313. 2000.

[39] Manuel G., Cannabinoids: potential anticancer agents. Nature Reviews Cancer. 2003. 3. 745.

[40] Najjar E. I. N., Anti-colon cancer effects of Salograviolide A isolated from Centaurea ainetensis. Oncol Rep, 19(4). 897. 2008.

[41] Ghantous A., Tayyoun A.A., Lteif G. A., Saliba N. A., GaliMuhtasib G., El-Sabban M., Darwiche N. Purified salograviolide A isolated from Centaurea ainetensis causes growth inhibition and apoptosis in neoplastic epidermal cells. International Journal of Oncology, 32(4). 841. 2008.

[42] Ho Y. C., Yang S.F., Peng C. Y., Chou M. Y., Chang Y. C., Epigallocatechin-3-gallate inhibits the invasion of human oral cancer cells and decreases the productions of matrix etalloproteinases and urokinase-plasminogen activator. Journal of Oral Pathol Medicine, 36. 588. 2007.

[43] Nishikawa T., Nakajima T., Moriguchi M., Jo M., Sekoguchi S., Ishii M. et al., A green tea polyphenol, epigalocatechin-3-gallate, induces apoptosis of human hepatocellular carcinoma, possibly through inhibition of Bcl-2 family proteins. Journal of Hepatology, 44. 1074. 2006.

[44] Spinella F., Rosano L., Decandia S., Di C.V., Albini A., Elia G. Natali P.G., Bagnato A., Antitumor effect of green tea polyphenol epigallocatechin-3-gallate in ovarian carcinoma cells: evidence for the endothelin-1 as a potential target. Exp Biol Med, 231. 1123. 2006 a.

[45] Spinella F., Rosano L., Di C.V., Decandia S., Albini A., Nicotra M.R., Natali P.G., Bagnato A., Green tea polyphenol epigallocatechin-3-gallate inhibits the endothelin axis and downstream signaling pathways in ovarian carcinoma. Mol Cancer Therapy, 5. 1483. 2006 b.

[46] Hwang J. T., Ha J., Park I. J., Lee S. K., Baik H. W., Kim Y. M., Park O. J., Apoptotic effect of EGCG in HT-29 colon cancer cells via AMPK signal pathway. Cancer Letters, 247. 115. 2007.

[47] Peng G., Dixon D.A., Muga S. J., Smith T.J., Wargovich M. J., Green tea polyphenol (-)-epigallocatechin-3-gallate inhibits cyclooxygenase-2 expression in colon carcinogenesis. Molecular Carcino, 45. 309. 2006.

[48] Hu Z., Yang Y., Ho P.C., Chan S. Y., Heng P. W., Chan E., Duan W., Koh H.L., Zhou S., Herb-drug interactions: a literature review. Drugs, 65. 1239. 2005. 
[49] Kupchan S. M., Baxter R. L., Mezerein: antileukemic principle isolated from Daphne mezereum. Life Science, 187(4177). 652. 1975.

[50] Coyle T., Levante S., Shetler M., Winfield J., In vitro and in vivo cytotoxicity of gossypol against central nervous system tumor cell lines. Journal of Neuro-Oncology, 19. 25. 1994.

[51] Gilbert N.E., Reilly J. E., Chang C. J., Lin Y. C., Brueggemeier R.W., Antiproliferative activity of gossypol and gossypolone on human breast cancer cells. Life Sciences, 57. 61. 1995.

[52] Liang X. S., Rogers A. J., Webber C. L., Ormsby T.J., Tiritan M.E., Maltin S.A., et al., Developing the gossypol derivatives with enhanced antitumor activity. Investigational New Drugs, 13. 181. 1995.

[53] Wu D., An overview of the clinical pharmacology and therapeutic potential of gossypol as a male contraceptive agent and in gynaecological disease. Drugs, 38 333. 1989.

[54] Gruenwald J., Brendler T., Jaenicke C., Nontvale N.J., PDR for herbal medicines. Medical Economics, 77. 1998.

[55] Newell C.A., Anderson L.A., Hilpson D., Herbal Medicine: A guide for healthcare professionals. Pharmaceutical Press, London. 1996.

[56] Frederico P., Rafael C.D., Dalton D. J., Miriam T. P. L., Nadia R. B., Antioxidant and cytotoxic activities of Centell asiatica. International Journal of Molecular Science, 10. 3713. 2009.

[57] Baby T. D., Kuttan G., Paddikkala. Cytotoxic and antitumour properties of certain taxa of Umbelliferae with special reference to Centella asiatica L. Journal of Ethnopharmacology, 48(1). 53. 1995.

[58] Punturee K., Wild C. P., Vinitketkumneum U. V., Thai medicinal plant modulating nitric oxide and tumour necrosis factor-alpha in J774. 2 mouse macrophages. Journal of Ethnopharmacology, 95(2-3). 183. 2004

[59] Huang Y. H., Zhang S. H., Zhen R., Xu X. D., Zhen Y. S., Asiaticoside inducing apoptosis of tumour cells and enhancing antitumour activity of vincristin. Ai Zheng, 23(12). 1599. 2004.

[60] Park B.C., Bosire K. O., Lee E. S., Lee Y. S., Kim J. A., Asiatic acid induced apoptosis in SK-MEL-2 human melanoma cells. Cancer Letters, 218(1). 81. 2005.

[61] Alecu M., Ursaciuc C., Halalau F., Photodynamic treatment of basal cell carcinoma and squamous cell carcinoma with hypericin. Anticancer Research, 18, 4651, 1998.

[62] Wada A., Sakaeda T., Takara K., Hirai M., Kimura T., Ohmoto N., et al., Effects of St John's wort and hypericin on cytotoxicity of anticancer drugs. Drug Metabolism \& Pharmacokinetics, 17(5). 467. 2002.

[63] Martarelli D., Martarelli B., Pediconi D., Nabissi M.I., Perfumi M., Hypericum perforatum methanolic extract inhibits growth of human prostatic carcinoma cell line orthotopically implanted in nude mice. Cancer Letters, 210(1). 27. 2004.

[64] Garrido-Garrido G., Martinez-Sanchez G., Pardo-Andreu G., Garcia-Rivera D., Hernandez-Casana P., Rodeiro-Guerra I., Guevara-Garcia M., Delgado-Hernandez R., Nunez-Selles A.J., Recent advances in the research \& development of an aqueous stem bark extract obtained from Mangifera indica L. Recent Developments in Medicinal Plant Research, 9. 169. 2007.

[65] Tamayo D., Mari E., Gonzalez S., Guevara M., Garrido G., Delgado R., Marchioli R., Nunez A.J., Vimang as natural antioxidant supplementation in patients with malignant tumours. Minerva Medica, 92. 95. 2001.

[66] Nunez A., Castro H., Aguero A.J., Gonzalez J., Naddeo F., De S.F., Rastrelli L., Isolation and quantitative analysis of phenolic antioxidants, free sugars and polyphenols from Mango (Mangifera indica L.) stem bark aqueous decoction used in Cuba as a nutritional supplement. Journal of Agriculture Food Chemistry, 50. 762. 2002.

[67] Zhen H. S., Study of anticancer effect in vivo of active fraction from Nervillia fordii.Zhong. Yao Cai, 30(9). 1095. 2007.

[68] Narisa K., Jenny M. W., Heather M. A. C., Cytotoxic Effect of Four Thai Edible Plants on Mammalian Cell Proliferation. Thai Pharmaceutical and Health Science Journal, 1(3). 189. 2006.

[69] Roy M. K., Nakahara K., Na T. V., Trakoontivakorn G., Takenaka M., Isobe S., et al., Baicalein, a flavonoid extracted from a methanolic extract of Oroxylum indicum inhibits proliferation of a cancer cell line in vitro via induction of apoptosis. A. Pharmazie, 62(2). 149. 2007.

[70] Nakahara K., Onishi K. M., Ono H., Yoshida M., Trakoontivakorn G., Antimutagenic activity against trp-P-1 of the edible Thai Plant: Oroxylum indicum Vent. Bioscience Biotechnology \& Biochemistry, 65(10). 2358. 2001.
[71] Tepsuwan A., Furihata C., Rojanapo W., Matsuhima T. Genotoxicity and cell proliferative acitivity of a nitrosated Oroxylum indicum Vent fractioin in the pyloric mucosa of rat stomact. Mutatant Research, 281(1). 55. 1992.

[72] Lotufo L. V. C., Khan M. T. H., Ather A., Wilke D. V., Jimenez P.C., Pessoa C., et al., Studies of the anticancer potential of plants used in Bangladeshi folk medicine. Journal of Ethnopharmacology, 99. 21. 2005.

[73] Kumar R.A., Rajkumar V., Guha G., Mathe L., Therapeutic Potentials of Oroxylum indicum Bark Extracts. Chinese Journal of Natural Medicines, 8(2). 121. 2010.

[74] Jenna K. J., Joy K. L., Kuttan R., Effect of Emblica officinalis, Phyllanthus amarus and Picrorrhiza kurroa on NNitrosodiethylamine induced hepatocardinogenesis. Cancer Letters, 136. 11. 1999.

[75] Morita H., Yamamiya T., Takeya K., Itokawa H., New antitumour bicyclic hexapeptides, RA-IX, XII, XIII and XIV from Rubia cordifolia. Chemical and Pharmaceutical Bulletin, 40(5). 1352 S. 1992.

[76] Morita H., Yamamiya T., Takeya K., Conformational Recognition of RA - XII by 80 S ribosomes: a different line broadening study in 1H NMR spectroscopy. Chemical and Pharmaceutical Bulletin, 41(4). 781. 1993.

[77] Itokawa H., Wang X., Lee K. H., Homoharringtonine and related compounds, in Anticancer Agents from Natural Products. Edited by Cragg GM, Kingston DGI, Newman DJ. Brunner-Routledge Psychology Press, Taylor \& Francis Group, Boca Raton, Chapter 4, 47. 2005.

[78] Gupta P.P., Srimal R. C., Verma N., Tandon J. S., Biological Activity of Rubia cordifolia and Isolation of an Active Principle. Pharmaceutical Biology, 37(1). 46. 1999.

[79] Abderrahman S. M., Mitodepressive Effect of Rubia cordifolia Extract on the Bone Marrow Cells of Mice. Cytologia, 69(3). 307. 2004.

[80] Son J. K., Jung J. H., Lee C. S., Moon D.C., Choi S.W., Min B.S., Woo M. H., DNA Topoisomerases I and II Inhibition and Cytotoxicity of Constituents from the Roots of Rubia cordifolia. Chem Inform, 38(2). 15. 2006.

[81] Nizamutdinova I. T., Lee G. W., Lee J. S., Cho M. K., Son K. H., Jeon S. J. et al., Tanshinone I suppresses growth and invasion of human breast cancer cells, MDA- MB- 231, through regulation of adhesion molecules. Carcinogenesis, 29(10). 1885. 2008.

[82] Yoon Y., Kim Y., Jeon W. K., Park H.J., Sun H.J., Tanshinone IIA isolated from Salvia miltiorrhiza B. induced apoptosis in HL60 human premyelocytic leukemia cell line. Journal of Ethnopharmacology, 68(1-3). 121. 1999.

[83] Parajuli P., Joshee N., Rimando A.M., Mittal S., Yadav S. K., In vitro antitumor mechanisms of various Scutellaria extracts and constituent flavonoids. Planta Medica, 75(1). 41. 2009.

[84] Yin X., Zhou J., Jie C., Xing D., Zhang Y., Anticancer activity and mechanism of Scutellaria barbata extract on human lung cancer cell line A 549. Life Sciences, 17. 75(18). 2233. 2004.

[85] Wang X., Wei Y., Yuan S., Liu G., Lu Y., Zhang J., Wang W., Potential anticancer activity of tanshinone II A against human breast cancer. International Journal of Cancer, 116. 799. 2005.

[86] Lee C. Y., Sher H.F., Chen H. W., Liu C.C., Chen C. S., Lin C. S., Yang P.C., Tsay H. S, Chen J. J. W., Anticancer effects of tanshinone I in human non-small cell lung cancer. Molecular Cancer Therapy, 7. 3527. 2008.

[87] Ye F., Xui L., Yi J., Zhang W., Zhang D. Y., Anticancer activity of Scutellaria baicalensis and its potential mechanism. Journal of Alternative \& Complementary Medicine, 8(5). 567. 2002.

[88] Zahra T. N., Emami S.A., Asili J., Mirzaei A., Mousavi S. H., Analyzing Cytotoxic and Apoptogenic Properties of Scutellaria litwinowii Root Extract on Cancer Cell Lines. Available at http://ecam.oxfordjournals.org/cgi/content/full/nep214 (accessed on July 22, 2010).

[89] Katiyar S. K., Korman N.J., Mukhtar H., Agarwal R., Protective effects of silymarin against photocarcinogenesis in a mouse skin model. Journal of National Cancer Institute, 89(8). 556. 1997.

[90] Agarwal R., Agarwal C., Ichikawa H., Singh R.P., Agarwal B.B., Anticancer potential of silymarin: from bench to bed side. Anticancer Research, 26(6B). 4457. 2006.

[91] Kim S., Choi J. H., Lim H. I., Lee S. K., Kim W.W., Kim J. S., et al., Silibinin prevents TPA-induced MMP-9 expression and VEGF secretion by inactivation of the Raf/MEK/ERK pathway in MCF-7 human breast cancer cells, Phytomedicine, 16(6-7). 573. 2009.

[92] Li Y. L., Gan G. P., Zhang H. Z., Wu H. Z., Li C. L., Huang Y. P., Liu Y. W., Liu J. W., A flavonoid glycoside isolated from Smilax 
china L. rhizome in vitro anticancer effects on human cancer cell lines. Journal of Ethnopharmacology, 113(1). 115. 2007.

[93] Xu W., Liu J., Li C., Wu H. Z., Liu Y. W., Kaempferol-7-O-betaD-glucoside (KG) isolated from Smilax china L. rhizome induces G2/M phase arrest and apoptosis on HeLa cells in a p53independent manner. Cancer Letters, 264(2). 229. 2008.

[94] Yuan L.L., Guo P. G., Hui Z. Z., He Z. W., Chang L.L., Yong P. H., et al., A flavonoid glycoside isolated from Smilax china L. rhizome in vitro anticancer effects on human cancer cell lines. Journal of Ethnolpharmacology, 113. 115-124. 2007.

[95] Xu K. D., Wu Y., Wei D. L., Fang Z. Y., Xiao Y. L., Xiao C. Z., Zi C. Z., Bao C.C., The anti-tumor effects of alkaloids from the seeds of Strychnos nux-vomica on HepG2 cells and its possible mechanism. Journal of Ethnopharmacology, 106(2). 179. 2006.

[96] Rao P.S., Ramanadham M., Prasad M. N., Anti-proliferative effects of Syrychnos nux-vomica root extract on human multiple myeloma cell line- RPMI 8226. Food \& Chemical Toxicology, 47(2). 283. 2009.

[97] Sigstedt S.C., Evaluation of aqueous extracts of Taraxacum officinale on growth and invasion of breast and prostate cancer cells. International Journal of Oncology. 32(5). 1085. 2008.

[98] Hyun N. K., Seung H.H., Bong K. S., Cheorl H. K., Young H. Y., Hyung M. K., Taraxacum officinale induces cytotoxicity through TNF- $\alpha$ and IL- $1 \alpha$ secretion in Hep G2 cells. Life Sciences, 74(9). 1149. 2004.

[99] Kaur S., Grover I. S., Singh M., Kaur S., Antimutagenesity of hydrolyzable tannins from Terminalia chebula in Salmonella typhimerium. Mutagen Research, 419(1-3). 169. 1998.

[100] Arora S., Kaw K., Kaur S., Indian Medicinal Plants as reserver of protective phytochemicals, Tetragenesis. Carcinogenesis and Mutagenesis, 23(1). 295. 2003.

[101] Saleem M., Hushum M., Harkonen P., Pihlaja K., Inhibition of cancer cell growth by crude extract and phenolics of Terminalia chebula fruit. Journal of Ethnopharmacology, 81. 327. 2002.

[102] Lecia J. G., Jetaime R., Ernest B. I., Vernonia amygdalina: Anticancer activity, Authentication, and Adultration detection. International Journal of Environment Research: Public Health, 5(5). 342. 2008.

[103] Ali M., Shuaib M., Withanolides from the stem bark of Withania somnifera. Phytochemistry, 44(6). 1163. 1997.

[104] Chakraborti S. K., De B. K., Bandyopadhyay T., Variations in the Antitumor Constituents of Withania somnifera. Experientia, 30(8). 852. 1974.

[105] Devi P. U., Akagi K., Ostapenko V., Tanaka Y., Sugahara T., Withaferin A: a new radiosensitizer from the Indian medicinal plant Withania somnifera. International Journal of Radiational Biology, 69(2). 193. 1996.

[106] Prakash J., Gupta S. K., Dinda A. K., Withania somnifera root extract prevents DMBA-induced squamous cell carcinoma of skin in Swiss albino mice, Nutr. Cancer, 42(1). 91. 2002.

[107] Jayaprakasam B., Zhang Y., Seeram N., Nair M., Growth inhibition of tumor cell lines by withanolides from Withania somnifera leaves. Life Sciences, 74(1). 125. 2003.

[108] Singh N., Singh S.P., Nath R., Prevention of urethane-induced lung adenomas by Withania somnifera (L.) Dunal in albino mice. International Journal of Crude Drug Research, 24. 90. 1986.

[109] Gupta Y. K., Sharma S.S., Rai K., Katiyar C. K., Reversal of paclitaxel induced neutropenia by Withania somnifera in mice. Indian Journal of Physiology \& Pharmacology, 45(2). 253. 2001.

[110] Katiyar S. K., Agarwal R., Mukhtar H., Inhibition of tumor promotion in SENCAR mouse skin by ethanol extract of Zingiber officinale rhizome. Cancer Research, 56(5). 1023. 1996.

[111] Brown A. C., Ginger's inhibition of rat colonic adenocarcinoma cells proliferation angiogenesis in vitro. Phytotherapy Research, 32. 2008.

[112] Abdullah S., Abidin S. A. Z., Murad N. A., Suzana M., Ngah W. Z. W., Yusof Y. A. M., Ginger extract (Zingiber officinale) triggers apoptosis and G0/G1 cells arrest in HCT 116 and HT 29 colon cancer cell lines. African Journal of Biochemistry Research, 4(4). 134. 2010.

[113] Willaman J.J., Hui-Li L., Lloydia, 33(3A). 1. 1970.

[114] Sehgal R., Roy S., Kumar V. L., Evaluation of cytotoxic potential of latex of Calotropis procera and Podophyllotoxin in Allium cepa root model. Biocell, 30(1). 9. 2006.
[115] Foss P., Ellipticine: An indole alkaloid isolated from Ochrosia ellipitica. Molecular Pharmacology, 42. 590. 1992.

[116] Hong R. L., Spohn W. H., Hung M. C., Curcumin inhibits tyrosine kinase activity of p185neu and also depletes p 185neu. Clinical Cancer Research, 5. 1884. 1999.

[117] Gerald R., Palesa N., The natural abundance of L-Canavanine, an active anticancer agent, in alfaalfa, Medicago sativa (L.). Laboratory of Biochemical Ecology, University of Kentucky, Lexington, USA.

[118] Madhuri L., Pandey G., Some anticancer medicinal plants of foreign Origin. Current Science, 96(6). 25. 779. 2009.

[119] Desai A.G., Medicinal plants and cancer chemoprevention. Curr Drug Metabolism, 9(7). 581. 2008.

[120] Mohammad S., Anticancer agents from medicinal plants. Bangladesh Journal of Pharmacology, 1. 35. 2006.

[121] Kelland L. R., Flavopiridol, the first cyclic-dependent kinase inhibitor to enter the clinic: current status. Expert Opinion Investigational Drugs, 9. 2903. 2000.

[122] Christian M. C., Pluda J. M., Ho T. C., Arbuck S. G., Murgo A. J., Sausville E. A., Promising new agents under development by division of cancer treatment, diagnosis, and centers of the National Cancer Institute. Semin Oncology, 13. 2643. 1997.

[123] Meijer L., Raymond L., Roscovitine and other purines as kinase inhibitors: From starfish oocytes to clinical trials. Accounts Chem Res, 36. 417. 2003.

[124] Pettit G. R., Singh S. B., Niven M. L., Hamel E., Schmit J. M., Isolation, structure, and synthesis of combretastatins A-1 and B-1, potent new inhibitors of microtubule assembly, derived from Combretum caffrum. Journal Natural Products, 50. 119. 1987.

[125] Pettit G. R., Singh S. B., Boyd M. R., Hamel E., Pettit R., Schmit J. M. et al. Antineoplastic agents. 291. Isolation and synthesis of combretastatins A-4, A-5 and A-6. Journal of Med Chem, 38. 1666. 1995

[126] Ohsumi K., Nakagawa R., Fukuda Y., Hatanaka T., Morinaga Y., Nihei Y. et al. New combretastatin analogues effective against murine solid tumors: design and structure-activity relationship. Journal of Med Chem, 41. 705. 1998.

[127] Cichewitz R. H., Kouzi S.A., Chemistry, biological activity, and chemotherapeutic potential of betulinic acid for the prevention and treatment of cancer and HIV infection. Medical Research Reviews, 24. 90. 2004.

[128] Pisha E., Chai H., Lee I. S., Chagwedera T. E., Farnsworth N. R., Cordell G. A. et al. Discovery of betulinic acid as a selective inhibitor of human melanoma that functions by induction of apoptosis. Natural Medicine, 1. 1046. 1995.

[129] Nahar N., Das R.N., Shoeb M., Marma M.S., Aziz M.A., Mosihuzzaman M., Four triterpenoids from the bark of Zizyphus rugosa and Z. oenoplia. Journal of Bangladesh Academy of Science, 21. 151. 1997.

[130] Balunas M. J., Kinghorn A. D. Drug discovery from medicinal plants. Life Sciences, 78. 431. 2005.

[131] Silva G. L., Cui B., Chavez D., You M., Chai H.B., Rasoanaive P. et al., Modulation of the multidrug-resistance phenotype by new tropane alkaloids aromatic esters from Erythroxylum pervillei. Journal of Natural Products, 64. 1514. 2001.

[132] Mi Q., Cui B., Silva G.L., Lantvit D., Lim E., Chai H. et al., A novel tropane alkaloid that reverses the multidrug-resistance phenotype. Cancer Research, 61. 842. 2001.

[133] Mi Q., Cui B., Silva GL, Lantvit D, Lim E, Chai H et al.,A new tropane alkaloid aromatic ester that reverses the multidrugresistance phenotype. Anticancer Research, 23. 3607. 2003.

[134] Hwang B. Y., Su B.N., Chai H., Mi Q., Kardono L.B., Afriastini JJ et al., Silvestrol and episilvestrol, potential anticancer rocaglate derivatives from Aglaila silvestris. Journal of Organic Chemistry, 69. 3350. 2004.

[135] Shoeb M., Celik S., Jaspars M., Kumarasamy Y., MacManus S., Nahar L. et al., Isolation, structure elucidation and bioactivity of schischkiniin, a unique indole alkaloid from the seeds of Centaurea schischkinii. Tetrahedron, 61. 9001. 2005.

[136] Altmann K. H., Cachoux F., Feyen F., Gertsch J., Kuzniewski C. N., Wartmann M., Natural products as leads for anticancer drug discovery: discovery of new chemotypes of microtubule stabilizers through reengineering of the epothilone scaffold, Chimia (Aarau), 64(1-2), 8-13, 2010. 